\title{
Population structure of Octopus defilippi (Verany, 1851) from the Gulf of Suez, Red Sea, Egypt.
}

\author{
Azza A. El-Ganainy and Rafik Riad \\ National Institute of Oceanography and Fisheries, B.O. Box 182, Suez, Egypt. \\ E-mail address: azzaelgan@yahoo.com
}

\begin{abstract}
$\mathrm{O}$ ctopuses are relatively abundant in the trawl landings of the Gulf of Suez; though they were considered discarded species till 1990's, but currently they have a commercial importance. The population structure and level of exploitation of the Octopus defilippi were studied using the length frequency distribution of samples collected from the Gulf of Suez. Some morphometric relationships were estimated where the mantel length, total weight potential equation was found to be $\mathrm{W}=0.7087 \mathrm{~L}^{2.646}$ for males and $\mathrm{W}=0.9118 \mathrm{~L}^{2.3629}$ for females. The length distribution pattern showed that females reach larger lengths than males. The population appeared to be structured in two cohorts for males and three for females. Growth of both sexes was fast and could be described well by the von Bertalanffy growth formula. The estimated asymptotic length for combined sexes was $\mathrm{ML}_{\infty}=9.0 \mathrm{~cm}$ and the growth coefficient was $\mathrm{K}$ $=0.94 \mathrm{y}^{-1}$. The overall sex ratio of males to females was 1: 0.5 . The total and natural mortality rates were high for both sexes, where the estimated values were $\mathrm{Z}=3.341 \mathrm{y}^{-1}$ and $\mathrm{M}=1.43 \mathrm{y}^{-1}$. The current exploitation ratio $(\mathrm{E}=0.57)$ indicates that the Octopus population in the Gulf of Suez is overexploited.
\end{abstract}

Key words: population structure, Octopus defilippi , Suez Gulf

\section{INTRODUCTION}

There is a significant worldwide commercial interest in cephalopods for human consumption, where world catches have increased steadily throughout the last 50 years, with annual landings increased from 0.5 million tons in 1950 to 03.3 million tons in 2001 (FAO, 2003). The Atlantic longarm Octopus Octopus defilippi is characterized by extremely long arms; it is a typical inhabitant of littoral waters taken on sandy to muddy bottoms from 6 to $60 \mathrm{~m}$ depth. Octopuses are relatively abundant in the trawl landings of the Gulf of Suez; they were considered as discarded species till 1990's (El-Ganainy et al. 2005), but currently they have a relatively high occurrence and commercial importance in the trawl landings, representing about $2.74 \%$ of the total trawl catch (GAFRD, 2005). They are represented in the Gulf of Suez by two species namely $O$. vulgaris and $O$. defilippi.

Biological information on Octopuses in the Gulf of Suez is very scarce; only Riad and Gabr (2007) studied some morphometric relationships and natural 
mortality of $O$. vulgaris. There are some previous studies on the biology of relative Octopus species in other regions (Mangold, 1983; SaÂnchez and Obarti, 1993; Quetglas, et al. 1998; Hernandez-Garcia, et al. 2002; Katsanevakis and Verriopoulos 2006; Rueda and Fl'orez, 2007).

This study is the first attempt to investigate the growth, population structure and level of exploitation of Octopus defilippi in the Gulf of Suez to help in the proper management and sustainability of this species.

\section{MATERIALS AND METHODS}

Samples of Octopus defilippi were collected from the commercial trawlers operating in the Gulf of Suez during the fishing season of 2004. Specimens were sorted by sex and measured for dorsal mantel length DML $(\mathrm{cm})$ and weighed for total and gutted weight $(\mathrm{g})$.

The length frequency data were grouped at $0.5 \mathrm{~cm}$ intervals. The Bhattacharya (1967) method was applied to the pooled size distributions by sex, in order to identify the different cohorts and split the length distributions into normal components. The parameters of the Von Bertalanffy growth equation $\mathrm{L}_{\infty}$ and $\mathrm{k}$ were estimated by applying the method of Wetherall (1986). The resultant growth estimates were then used as seed values in ELEFAN I program (Pauly, 1984) for estimation of the best combination of $\left(\mathrm{L}_{\infty}\right.$ and $\left.\mathrm{k}\right)$. The reliability of these growth parameters were tested using the Munro's phi prime index $(\Phi)$ computed from the equation derived by Pauly \& Munro (1984)

The total mortality rate $(Z)$ was estimated for each sex separately and also for combined sexes by Jones and van Zalinge (1981) method. The natural mortality rate $(\mathrm{M})$ was estimated after King (1995) method as:

$$
M=-\ln [0.01] / t_{\max }
$$

Where $t_{\max }$ is the time required for a fish to reach $95 \%$ of the species $L \infty$, or the maximum age.

The instantaneous rate of fishing mortality $(\mathrm{F})$ was extracted as $\mathrm{F}=\mathrm{Z}$ $M$. The exploitation ratio $(E)$ was calculated as equal to the fraction of death caused by fishing $E=F / Z$. The size that generates optimum yield per recruit $\left(\mathrm{L}_{\text {opt }}\right)$ was estimated by Froese \& Binohlan (2000) empirical equation, and then it was compared with the length at first maturity $\left(\mathrm{L}_{\mathrm{m}}\right)$ and length at first capture $\left(\mathrm{L}_{\mathrm{c}}\right)$.

\section{Growth}

\section{RESULTS AND DISCUSSION}

Some morphometric relationships were investigated for each sex separately by fitting regressions to total length on total weight, mantel length on total weight and total length on mantel length (Fig.1) and Table (1). The slopes of the length weight regressions were statistically significant $\left(\mathrm{Ps}_{\mathrm{s}}<0.001\right)$, where females of this species reached larger sizes and gained more weights than males. The growth in weight was found to be allometrically negative in all three cases 
$(P>0.5)$. The negative allometry found in the length-weight relationship agrees with results obtained by other authors for Octopus species in other areas (Guerra and Manrõ̂̂quez, 1980; Smale and Buchan, 1981; SaÂnchez and Obarti, 1993; Quetglas et al., 1998 ; Riad and Gabr, 2004).
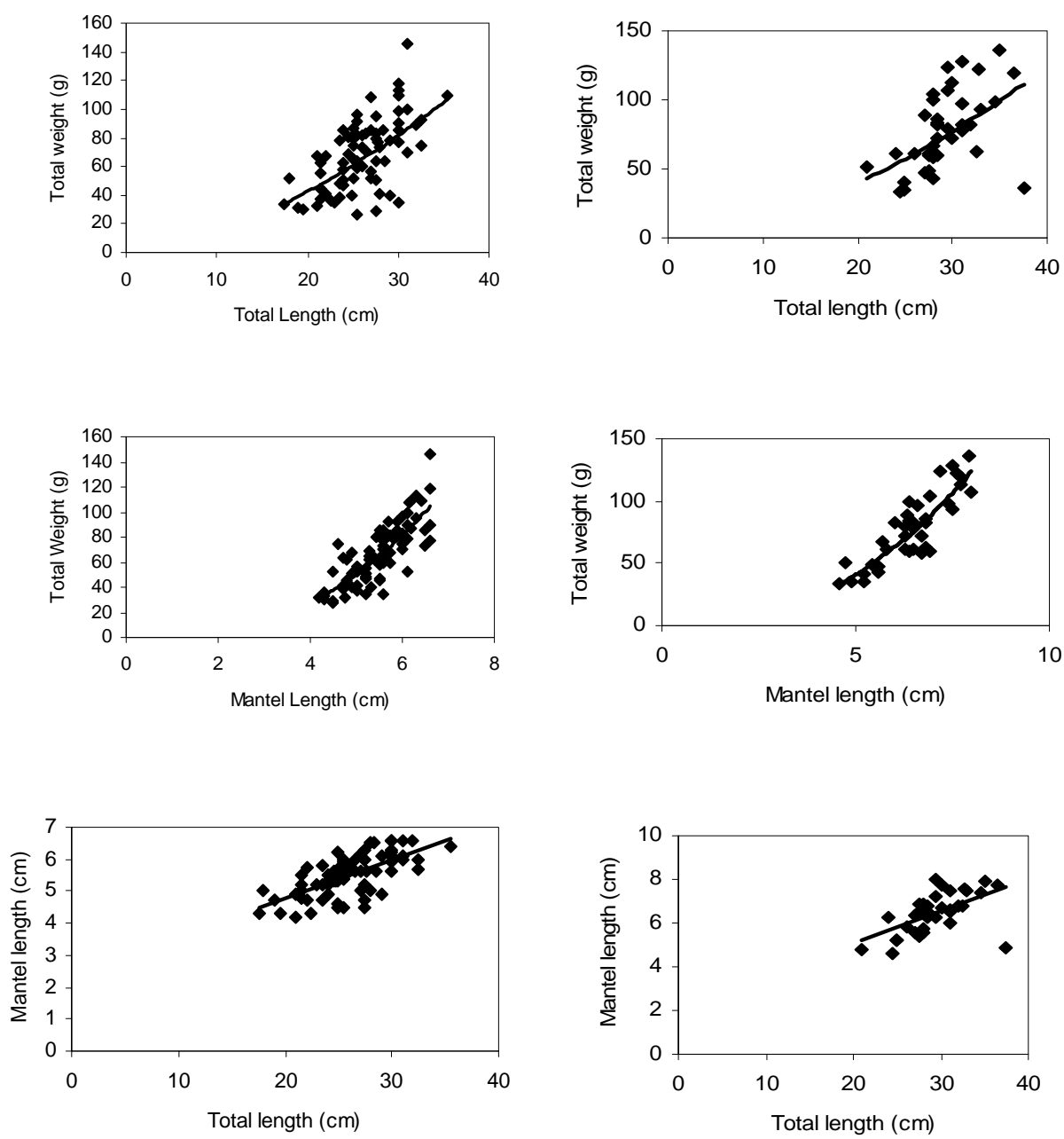

Fig (1) Different morphometric relationships for males and females Octopus defilippi collected from the Gulf of Suez 
Table (1): Different morphometric relationships of the Octopus O. defilippi from the Gulf of Suez ( $\mathrm{r}^{2}$ is the correlation coefficient).

\begin{tabular}{|l|l|c|c|}
\hline \multicolumn{1}{|c|}{ Parameters } & \multicolumn{1}{|c|}{ Relationship } & $\mathrm{r}^{2}$ & Variance of $\mathrm{b}$ \\
\hline Males & & & \\
Total length against total weight & $\mathrm{W}=0.3482 \mathrm{TL}^{1.6048}$ & 0.3428 & 0.0024 \\
Mantel length against total weight & $\mathrm{W}=0.7087 \mathrm{ML}^{2.646}$ & 0.6544 & 0.0025 \\
Total length against Mantel length & $\mathrm{ML}=0.1208+2.379 \mathrm{TL}$ & 0.4618 & 0.00017 \\
\hline Females & & & \\
Total length against total weight & $\mathrm{W}=2.857 \mathrm{TL}^{1.648}$ & 0.2520 & 0.0027 \\
Carapace length against total weight & $\mathrm{W}=0.9118 \mathrm{ML}^{2.3629}$ & 0.7683 & 0.0030 \\
Total length against Mantellength & $\mathrm{ML}=0.1465+2.1738 \mathrm{TL}$ & 0.9705 & 0.00017 \\
\hline
\end{tabular}

\section{Size composition}

Sampled Octopus ranged in size from 4.2 to $8.0 \mathrm{~cm}$ DML with an average of $5.81 \pm 0.84 \mathrm{~cm}$, and weighed between 27.0 to $146.0 \mathrm{~g}$ with an average of $71.39 \pm 25.89 \mathrm{~g}$. The lengths of females ranged from 4.6 to $8.0 \mathrm{~cm}$ with an average of $6.46 \pm 0.89 \mathrm{~cm}$ and the weight from 33.0 to $136.0 \mathrm{~g}$ with an average of $78.28 \pm 28.17 \mathrm{~g}$. The length of males ranged from 4.2 to $6.6 \mathrm{~cm} \mathrm{DML}$ with an average of $5.51 \pm 0.62 \mathrm{~cm}$, and the weight from 27.0 to $146.0 \mathrm{~g}$ with an average of $68.09 \pm 24.22 \mathrm{~g}$. The monthly length frequency distributions of 0.5 cm class intervals (dorsal mantel length) were pooled and presented in (Fig. 2). The smallest size fully recruited to the fishery was $4.2 \mathrm{~cm}$ for males and $4.6 \mathrm{~cm}$ for females.

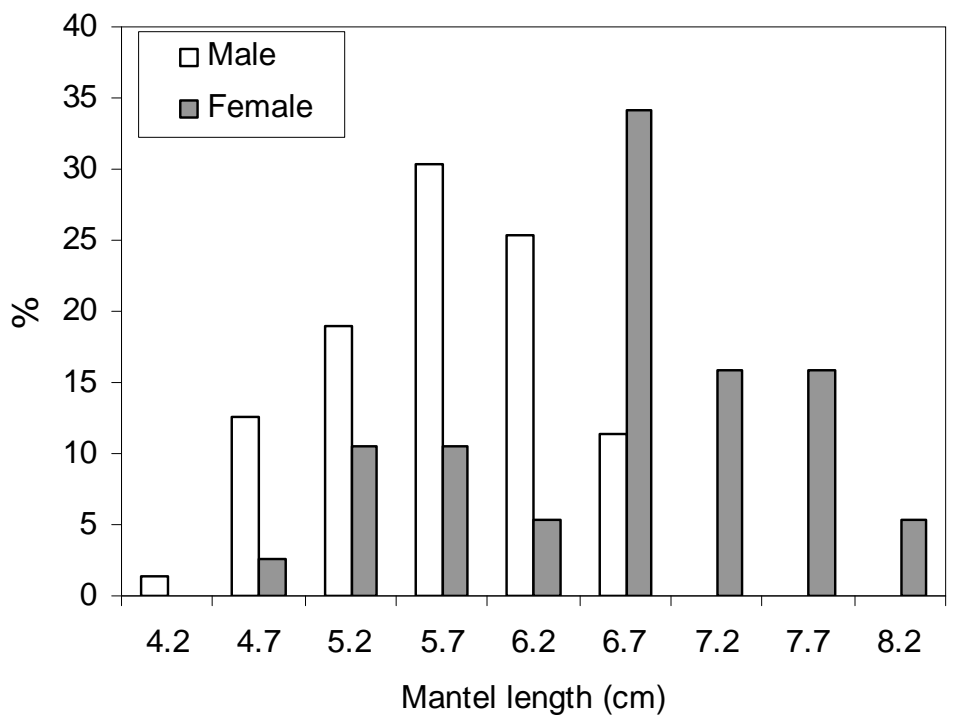

Fig (2) Mantel length frequency distribution of $O$. defilippi in the Gulf of Suez. 


\section{Sex ratio}

The variation in both the numbered and percentage of males and females in different length groups (Fig. 3) show that females reach larger sizes. The overall sex ratio of males to females was 1: 0.5 and the proportion of females was significantly lower than males $\left(\chi^{2} 48.1 ; \mathrm{P}<0.001\right)$. Fig. 3 shows that males largely outnumbered females up to the length interval $4.2-6.2 \mathrm{~cm}$, while females dominated the catch in the following length intervals. The same trend of sex ratio was recorded by Quetglas et al. (1998); Hernandez-Garcia et al. (2002) and Rueda and Fl'orez (2007) for O. vulgaris in the Mediterranean Sea.

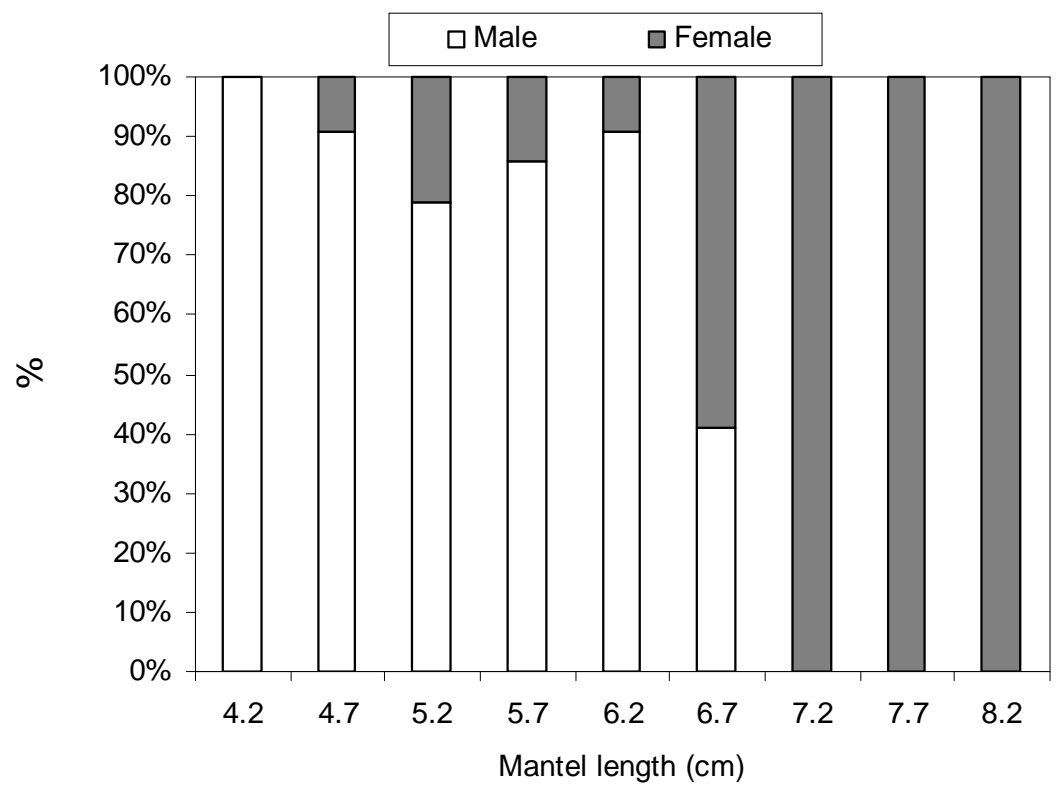

Fig (3) sex ratio by length group of $O$. defilippi from the Gulf of Suez.

\section{Population parameters}

The seasonal length distributions by sex were analyzed into normal components using Bhattacharya (1967) method. Two cohorts were identified for males with mean modal lengths of 5.0 and $6.1 \mathrm{~cm}$ (Fig 4a). For females three cohorts could be separated with modal lengths of 5.53, 6.88 and $7.45 \mathrm{~cm}$ (Fig $4 \mathrm{~b})$. The evolution of the population structure examined suggests a life-span of about 2 years and a maximum age of about 3 years for combined sexes. Herna'ndez-Lo'pez et al. (2001) estimated a lifespan of 12-13 months for $O$. vulgaris in the Canary Island waters, by counting the number of concentric rings on the upper beaks of 275 Octopuses. Katsanevakis and Verriopoulos (2006) stated that the lifespan of the common Octopus would be between 12 and 15 months. Several hypotheses have been made about longer-lived individuals (Mangold, 1983). 


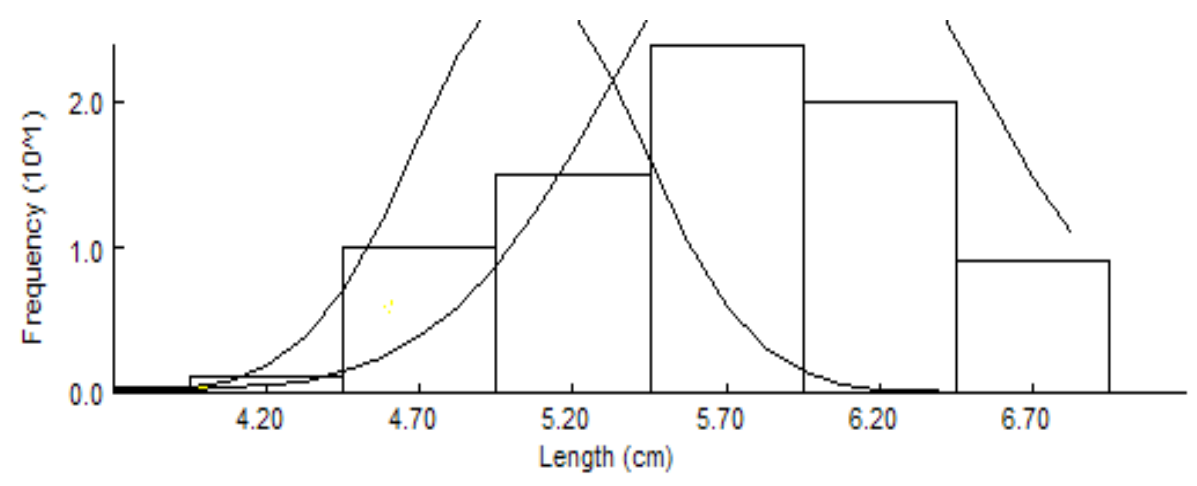

(A)

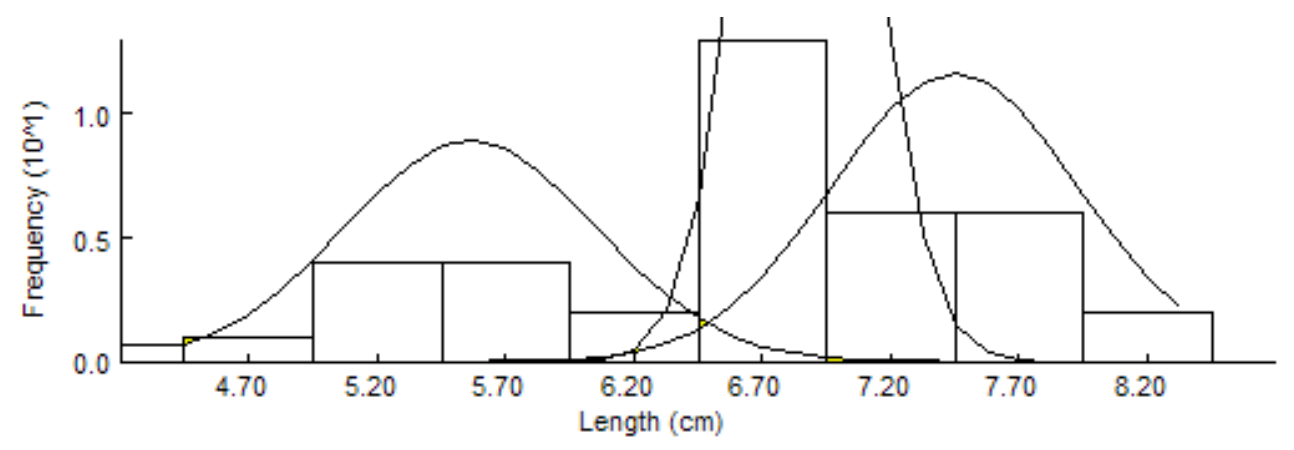

(B)

Fig. (4): Bhattacharya plots for Male (A) and Female (B) O. defilippi from the Gulf of Suez.

The estimated von Bertalanffy growth parameters that describe growth in length and weight $\left(\mathrm{L}_{\infty}, \mathrm{W}_{\infty}\right.$ and $\left.\mathrm{K}\right)$ and the derived growth performance index $(\Phi)$ are presented in Table (2). These results indicate that males have a relatively higher "K" value than females and they reach their asymptotic length faster than females. 
Table (2) Estimated values of the population parameters of Octopus defilippi from the Gulf of Suez.

\begin{tabular}{|c|c|c|c|}
\hline Parameter & Males & Females & Sexes combined \\
\hline Asymptotic length " $\mathrm{L}_{\infty}$ "cm & 7.70 & 9.10 & 9.00 \\
\hline Growth coefficient "K" & 1.10 & 0.93 & 0.94 \\
\hline Growth performance index " $\Phi "$ & 1.81 & 1.89 & 1.88 \\
\hline Total mortality rate "Z" & 2.78 & 3.11 & 3.34 \\
\hline Natural mortality rate "M" & 1.69 & 1.43 & 1.43 \\
\hline Fishing mortality rate "F" & 1.09 & 1.68 & 1.91 \\
\hline Length at first maturity $" \mathrm{~L}_{\mathrm{m}} " \mathrm{~cm}$ & 4.90 & 5.50 & 6.00 \\
\hline Optimum length ' $\mathrm{L}_{\text {opt }}$ "cm & 4.70 & 5.50 & 5.50 \\
\hline Exploitation rate "E" & 0.39 & 0.54 & 0.57 \\
\hline
\end{tabular}

The pooled length frequency distribution by sex was used for the estimation of the total mortality rate by applying the method of Jones and van Zalinge (1981) (Fig 5). The results show that the estimated total mortality (Z) for both sexes was nearly similar, while the estimated natural mortality rate $(\mathrm{M})$ was higher for males than females and the fishing mortality (F) was accordingly higher for males (Table 2).

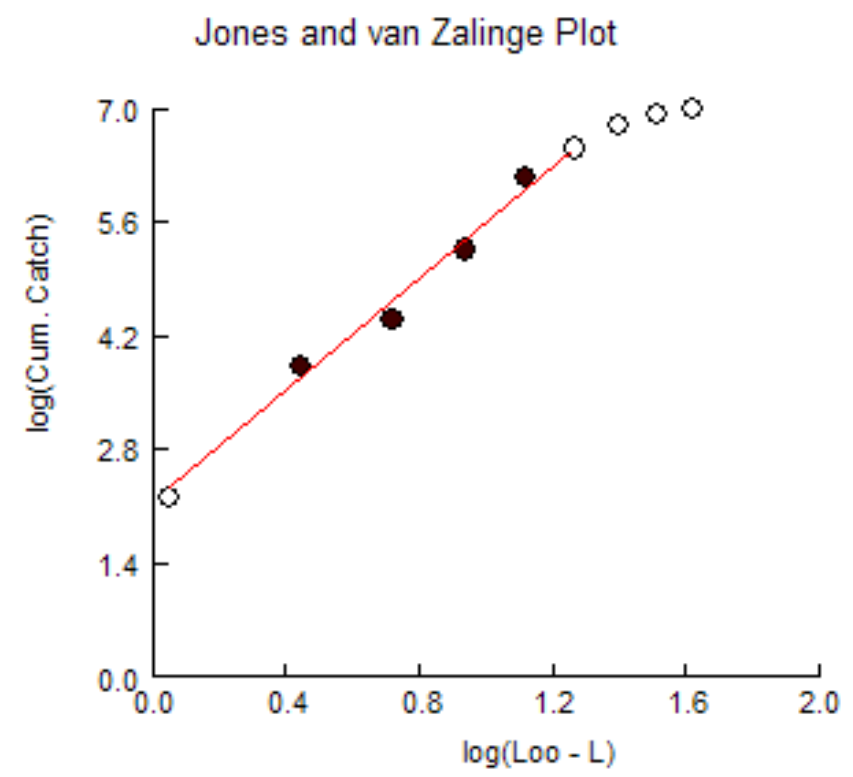

Fig (5) Jones and van Zalinge plot for the estimation of total mortality rate of $O$. defilippi from the Gulf of Suez. 
The estimated values of the exploitation rate were $E=0.39$ for males, 0.54 for females and 0.57 for combined sexes. According to Gulland (1971), the present estimated values of exploitation rate of $O$. defilippi indicated an overexploitation of this species in the Gulf of Suez.

\section{Optimum length}

The optimum length $\left(\mathrm{L}_{\mathrm{opt}}\right)$ for a given stock is defined as the intermediate length class, where the product of individuals times their average weight reached a maximum. $\mathrm{L}_{\text {opt }}$ and its $95 \%$ confidence intervals were estimated from the asymptotic length $\left(\mathrm{L}_{\infty}\right)$ using the empirical relationship of Froese and Binohlan (2000). The fishery would reach the maximum possible yield if it were to catch only fish of the optimum size (Beverton, 1992). The derived estimate of this optimum length for $O$. defilippi was $4.7 \mathrm{~cm}$ for males and $5.5 \mathrm{~cm}$ for females and $5.5 \mathrm{~cm}$ for combined sexes. It has been used with the length at first maturity $(\mathrm{Lm}=6.0 \mathrm{~cm}$ for combined sexes as derived from the empirical equation of Froese and Binohlan (2000) to evaluate the length frequency diagram (Fig. 6) for signs of growth overfishing, The figure indicates growth and recruitment overfishing, where the smallest fully recruited size to the fishery was $4.2 \mathrm{~cm}$ for males and $4.6 \mathrm{~cm}$ for both females and combined sexes, and the mean size of the catch calculated from the smallest fully recruited size was smaller than the estimated optimum size. It can be seen that the length at first capture $(\mathrm{Lc}=4.2 \mathrm{~cm})$ is smaller than the length at first maturity and the optimum length, the length at first capture for this population should be increased to obtain the maximum possible yield and to maintain the sustainability of the species.

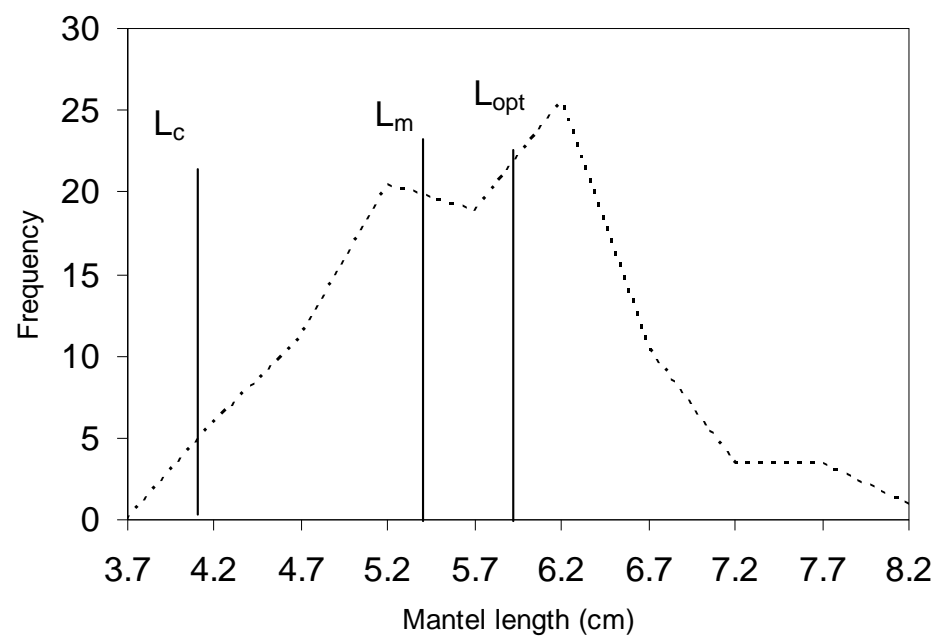

Fig (6) Length frequency diagram showing the optimum length, lengthat first maturity and length at first capture of O. defilippi from the Gulf of Suez. 


\section{REFERENCES}

Beverton, R. J. H. (1992). Patterns of reproductive strategy parameters in some marine teleost fishes. J. Fish Biol., 41 (B): 137-160

Bhattacharya, C.G. (1967). A simple method of resolution of a distribution into Gaussian components. Biometrics, 23:115-135

El-Ganainy, A.A.; Yassien, M. H. and Awad, E. I. (2005). Bottom trawl discards in the Gulf of Suez, Red Sea. Egyptian Journal of Aquatic Research, 31(special issue): $240-255$.

FAO. (2004). Fisheries Global Information System (FIGIS). World Wide Web electronic database (http://www.fao.org/fi/figis/index.jsp).

Froese, R. and Binohlan, C. (2000). Empirical relationships to estimate asymptotic length, length at first maturity and length at maximum yield per recruit in fishes with a simple method to evaluate length frequency data. J. Fish Biol., 56: 758-773.

GAFRD, (2005). General Authority for fish resources development, fish production in Egypt, Ministry of Agriculture, Cairo, 186pp.

Guerra, A. and ManrõÂquez, M.(1980). ParaÂmetros biomeÂtricos de Octopus vulgaris. Inv. Pesq., 44(1): 177-198.

Gulland, J. A.(1971). The Fish Resources of the Ocean. FAO Fish Tech. Pap., (97): 425pp.

Herna'ndez-Garc1'a, V.; Herna'ndez-Lo'pez, J. L. and Castro-Hdez, J. J. (2002).

On the reproduction of Octopus vulgaris off the coast of the Canary Islands. Fisheries Research, 57: 197-203.

Herna'ndez-Lo'pez, J. L.; Castro-Herna'ndez, J. J. and Herna'ndez-Garci'a, V. (2001). Age determined from the daily deposition of concentric rings on common Octopus (Octopus vulgaris) beaks. Fishery Bulletin US, 99: 679-684.

Jones, R. and van Zalinge, N.P. (1981): Estimations of mortality rate and population size for shrimp in Kuwait waters. Kuwait Bull. Mar. Sci., 2: 273-288. 
Katsanevakis, S and Verriopoulos, G. (2006). Seasonal population dynamics of Octopus vulgaris in the eastern Mediterranean. ICES Journal of Marine Science, 63: 151-160

King, M. (1995). Fisheries Biology, Assessment and Management. Fishing News Books, Oxford.

Mangold, K. (1983). Octopus vulgaris. In: Boyle, P. (Ed.).Cephalopod Life Cycles. Vol. I, Academic Press, London, pp. 335- 364.

Pauly, D. (1984). Fish population dynamics in tropical waters: a manual for use with programmable calculators. ICLARM Stud. Rev. 8: 325pp.

Pauly, D. and Munro, J.L. (1984). Once more on the comparison of growth in fish and invertebrates. ICLARM Fishbyte, 2(1): 21.

Quetglas A.; Alemany F.; Carbonell A. ; Merella P. and Sanchez P. (1998). Biology and fishery of Octopus vulgaris Cuvier, 1797, caught by trawlers in Mallorca (Balearic Sea, Western Mediterranean). Fisheries Research, 36: 237-249.

Fern'andez-Rueda, P. and Garc'ia-Fl'orez, L. (2007). Octopus vulgaris (Mollusca: Cephalopoda) fishery management assessment in Asturias (north-west Spain). Fisheries Research, $83: 351-354$.

Riad, R. and Gabr, H. R. (2007). comparative study on Octopus vulgaris (Cuvier, 1797) from the Mediterranean and Red Sea coasts of Egypt. Egyptian Journal of Aquatic Research, 33 (3): 140-146.

Sanchez, P. Obarti, R.(1993). The Biology and Fishery of Octopus vulgaris Caught with Clay Pots on the Spanish Mediterranean Coast. In: Okutani, T., R.K. O'Dor, T. Kubodera (Eds.), Recent Advances in Fisheries Biology. Tokai University Press, Tokyo. pp. 477- 487.

Smale, M. J. and Buchan, P. R.(1981). Biology of Octopus vulgaris off the east coast of South Africa. Mar. Biol., 65: 1-12.

Wetherall, J. A. (1986). A new method for estimating growth and mortality parameters for length frequency data. Fishbyte, 4 (1): 12-14. 